\title{
41SM91: A Frankston Phase Settlement on the Neches River at Lake Palestine, Smith County, Texas
}

Timothy K. Perttula

Heritage Research Center, Stephen F. Austin State University

Follow this and additional works at: https://scholarworks.sfasu.edu/ita

Part of the American Material Culture Commons, Archaeological Anthropology Commons, Environmental Studies Commons, Other American Studies Commons, Other Arts and Humanities Commons, Other History of Art, Architecture, and Archaeology Commons, and the United States History Commons

Tell us how this article helped you.

This Article is brought to you for free and open access by the Center for Regional Heritage Research at SFA ScholarWorks. It has been accepted for inclusion in Index of Texas Archaeology: Open Access Gray Literature from the Lone Star State by an authorized editor of SFA ScholarWorks. For more information, please contact cdsscholarworks@sfasu.edu. 


\section{SM91: A Frankston Phase Settlement on the Neches River at Lake Palestine, Smith County, Texas}

\section{Creative Commons License}

\section{(c) (1) (8)}

This work is licensed under a Creative Commons Attribution-NonCommercial 4.0 International License 


\title{
41SM91: A Frankston Phase Settlement on the Neches River at Lake Palestine, Smith County, Texas
}

\author{
Timothy K. Perttula
}

\section{Introduction}

Site 41SM91 is an ancestral Caddo habitation site on an upland landform east of the Neches River, in the area of Lake Palestine, a large reservoir constructed on the Neches River in the East Texas Pineywoods (Figure 1); the dam is located about $11 \mathrm{~km}$ south of the site (Johnson 1961:Figure 1). The site was found and recorded during a 1957 survey of the proposed reservoir flood pool, and Johnson (1961:230) described it as "a large Frankston Focus habitation site located in a cultivated field on the slope of a large hill to the east of the Neches floodplain". A large assemblage of ceramic vessel sherds were collected from the surface of the site during the archaeological survey, and these sherds are in the collections of the Texas Archeological Research Laboratory at the University of Texas at Austin.

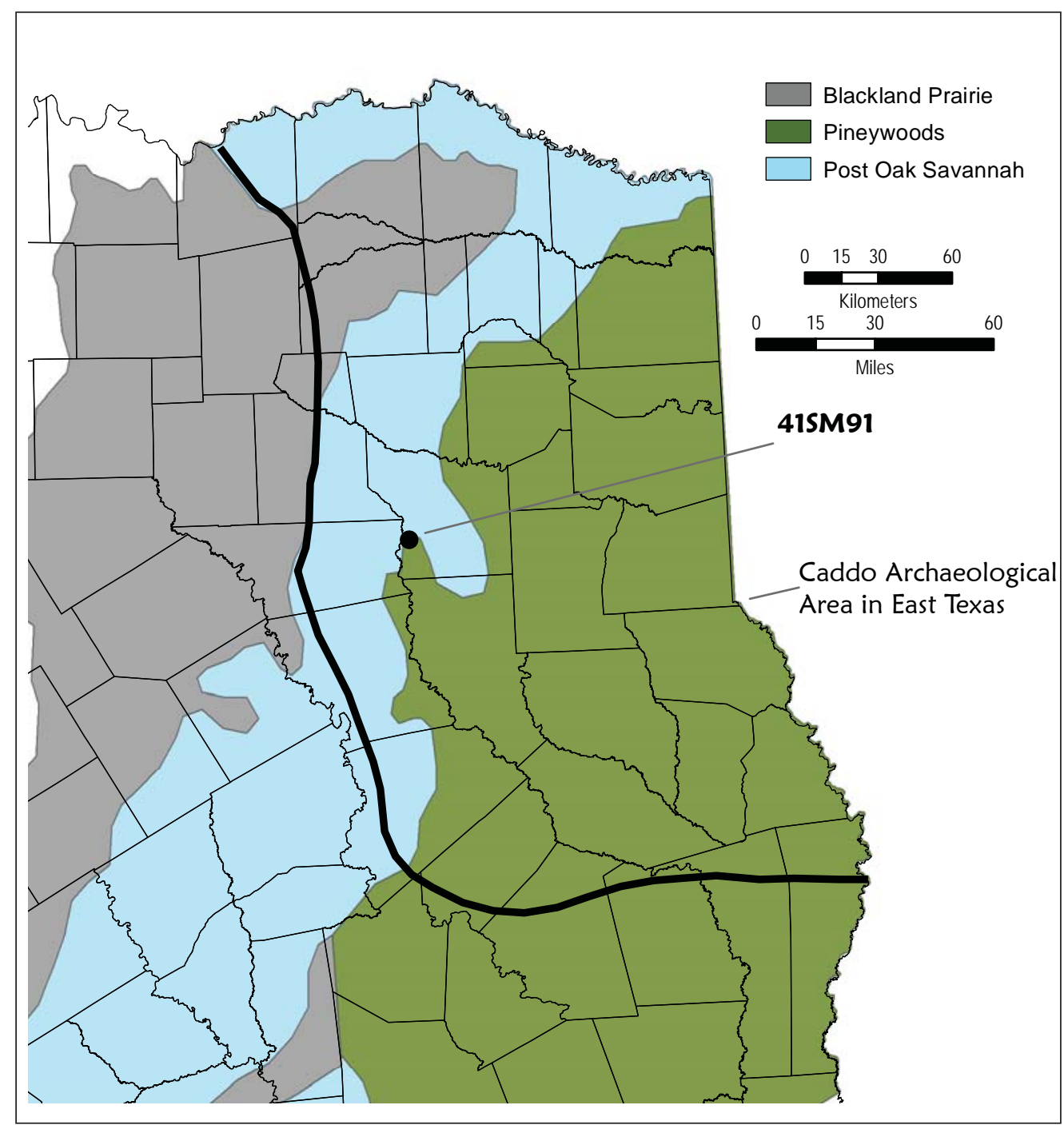

Figure 1. The location of 41SM91 in East Texas. 


\section{Ceramic Vessel Sherd Assemblage}

The 1957 surface collection from 41SM91 has 288 ceramic vessel sherds (Table 1), including 191 sherds with decorative elements from utility ware and fine ware vessels. The plain to decorated sherd ratio for this assemblage is 0.51 , consistent with a Late Caddo period, Frankston phase occupation in the upper Neches River basin.

Table 1. Ceramic sherd assemblage from 41SM91.

\begin{tabular}{llll}
\hline Ware & $\begin{array}{l}\text { Grog- } \\
\text { tempered }\end{array}$ & $\begin{array}{l}\text { Bone- } \\
\text { tempered }\end{array}$ & $\mathrm{N}$ \\
\hline Plain & 96 & 1 & 97 \\
Utility & 172 & 1 & 173 \\
Fine & 18 & - & 18 \\
\hline Totals & 286 & 2 & 288 \\
\hline
\end{tabular}

All three wares are almost exclusively from grog-tempered vessels ( 99.3 percent). Only 0.7 percent of the sherds are from bone-tempered vessels (see Table 1). The assemblage from 41SM191 is also dominated by decorated sherds from utility ware vessels: 90.5 percent of the decorated rim and body sherds are from utility ware vessels, compared to only 9.5 percent that are from engraved fine wares. About 76 percent of the sherds have brushed or brushed-incised decorative elements (Table 2). These brushed and brushed-incised sherds are from Bullard Brushed vessels (see Suhm and Jelks 1962) with a range of decorative elements based on the direction of brushing marks on vessel rim and body sections, as well as having occasional incised lines that either parallel or overlap the brushing marks.

Table 2. Decorative methods/elements represented in the utility ware and fine ware sherds from 41SM91.

Decorative method/ $\quad$ Rim $\quad$ Body N

Decorative element

Brushed

diagonal brushing marks

horizontal brushing marks

opposed brushing marks

overlapping brushing marks

parallel brushing marks

vertical brushing marks

$\begin{array}{lll}- & 1 & 1 \\ 2 & - & 2 \\ - & 11 & 11 \\ - & 14 & 14 \\ - & 103 & 103 \\ - & 2 & 2\end{array}$

\section{Brushed-Incised}

diagonal opposed incised lines (rim)-vertical

brushed (body)

opposed brushed-incised marks and lines

parallel brushed-incised marks and lines

$\begin{array}{lll}- & 1 & 1 \\ - & & \\ - & 3 & 3 \\ & 8 & 8\end{array}$

\section{Incised}

cross-hatched incised lines

diagonal opposed incised lines

horizontal and diagonal incised lines

incised triangle element

opposed incised lines

parallel incised lines

$\begin{array}{lll}- & 3 \\ - & 3 & 1 \\ - & 1 & 1 \\ - & 1 & 1 \\ - & 1 & 1 \\ - & 1 & 8\end{array}$


Table 2. Decorative methods/elements represented in the utility ware and fine ware sherds from 41SM91, cont.

\begin{tabular}{|c|c|c|c|}
\hline $\begin{array}{l}\text { Decorative method/ } \\
\text { Decorative element }\end{array}$ & Rim & Body & $\mathrm{N}$ \\
\hline \multicolumn{4}{|l|}{ Incised-Punctated } \\
\hline $\begin{array}{l}\text { diagonal incised lines and triangle el. filled } \\
\text { with tool punctates }\end{array}$ & 1 & - & 1 \\
\hline straight incised line between tool punctated rows & - & 1 & 1 \\
\hline \multicolumn{4}{|l|}{ Pinched } \\
\hline parallel pinched ridges & - & 1 & 1 \\
\hline \multicolumn{4}{|l|}{ Punctated } \\
\hline circular punctated rows & 1 & - & 1 \\
\hline horizontal tool punctated rows & 3 & - & 3 \\
\hline tool punctated rows & - & 6 & 6 \\
\hline \multicolumn{4}{|l|}{ Engraved } \\
\hline cross-hatched engraved zone & - & 1 & 1 \\
\hline curvilinear engraved lines & - & 3 & 3 \\
\hline $\begin{array}{l}\text { curvilinear engraved line and hatched pendant } \\
\text { triangle elements }\end{array}$ & - & 1 & 1 \\
\hline diagonal and diagonal opposed engraved lines & - & 1 & 1 \\
\hline horizontal engraved line below lip & 1 & - & 1 \\
\hline horizontal and diagonal engraved lines & - & 1 & 1 \\
\hline horizontal and opposed curvilinear engraved lines & 1 & - & 1 \\
\hline opposed curvilinear engraved lines & 1 & - & 1 \\
\hline parallel engraved lines & - & 3 & 3 \\
\hline parallel engraved lines with linear tick marks & - & 1 & 1 \\
\hline straight engraved line & - & 4 & 4 \\
\hline Totals & 10 & 181 & 191 \\
\hline
\end{tabular}

Other utility wares have incised (7.9 percent of the decorated sherds) (Figure 2a-b), incised-punctated (1.0 percent) (Figure $2 \mathrm{c}$ ), pinched ( 0.5 percent), and punctated (5.3 percent) decorative elements. The incised and incised-punctated sherds are from Maydelle Incised jars, and the one pinched sherd is from a Killough Pinched vessel (see Suhm and Jelks 1962); both utility ware types are found in Frankston phase ceramic assemblages. The tool and circular punctated rim and body sherds are from an undefined upper Neches River basin Caddo utility ware.

There are two Poynor Engraved rim sherds in the 41SM91 collection, probably var. Cook (Perttula 2011:Figure 6-64c-d) (Figure 3a-b). Another sherd, from a carinated bowl, is a Var. $Q$ example of Poynor Engraved (Perttula 2011:Figure 6-65) (Figure 3c). These varieties of Poynor Engraved are most common in sub-phase 2 (ca. A.D. 1480-1560) contexts of the Frankston phase (Perttula 2011:Table 6-37), but var. Cook vessels are also present in ca. A.D. 1560-1650 contexts in the region. One bottle sherd is from a Hume Engraved, var. unspecified vessel (Figure 3d); Hume Engraved vessels may have begun to be manufactured in the upper Neches River basin after ca. A.D. 1480. 


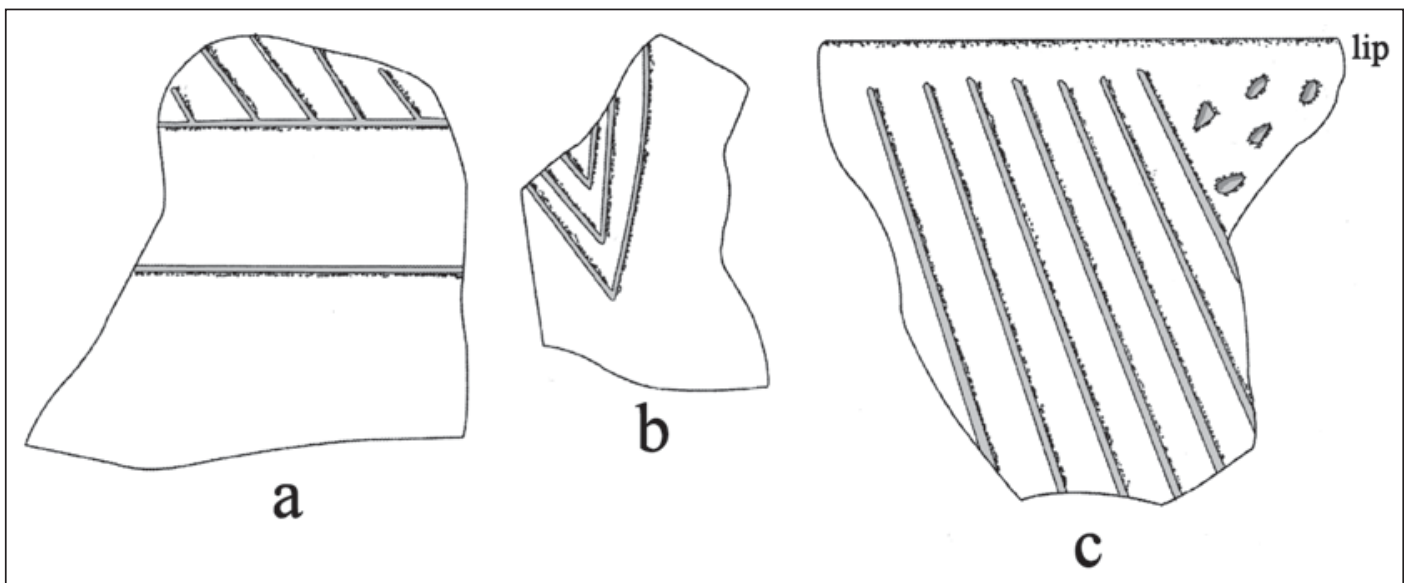

Figure 2. Selected decorative elements on utility ware sherds from 41SM91.

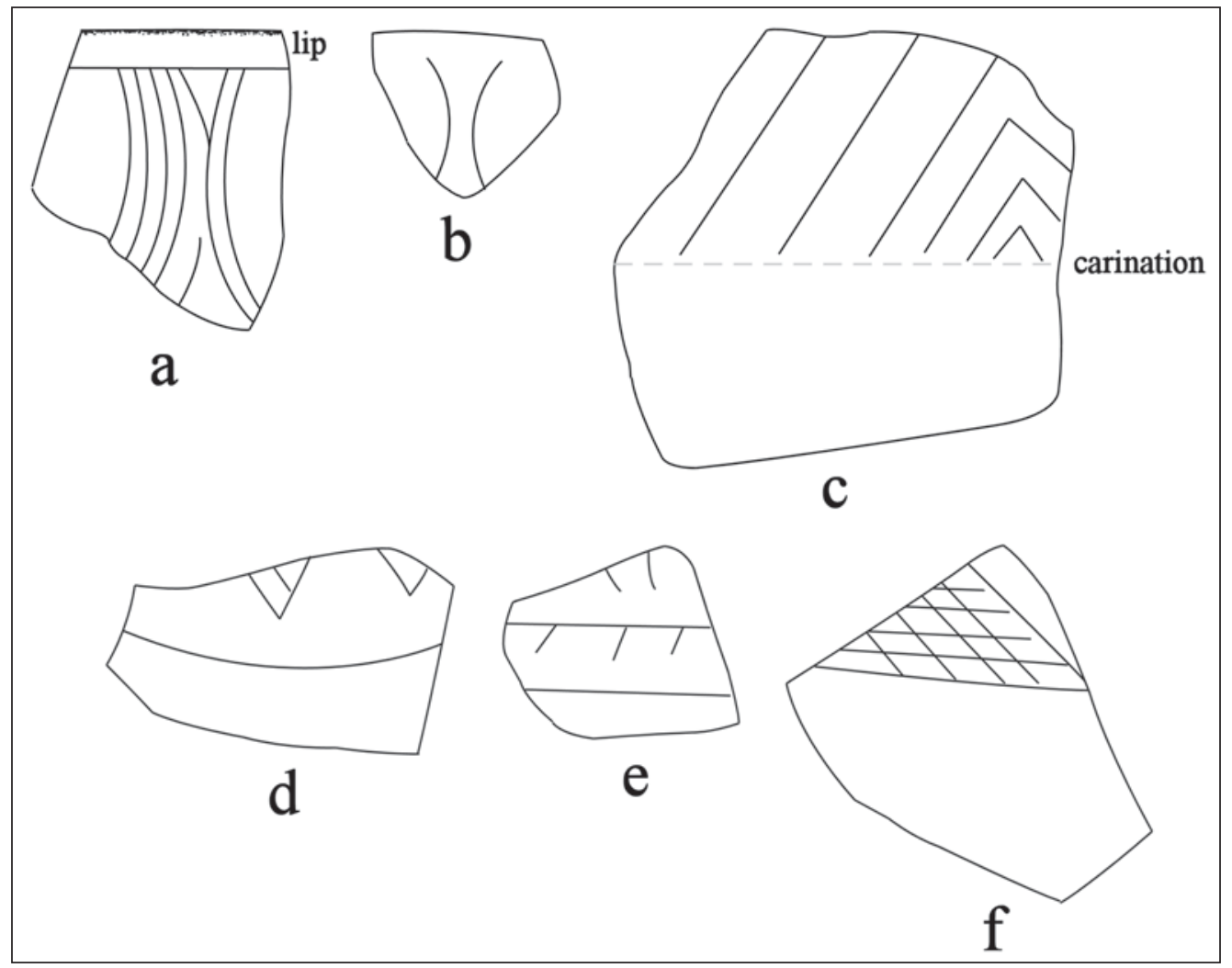

Figure 3. Selected decorative elements on fine ware sherds from 41SM91.

There are two other distinctive engraved sherds in the fine wares from 41SM91. One has parallel engraved lines with linear tick marks (see Figure 3e), which may be from a post-A.D. 1680 Patton Engraved, var. Allen vessel (see Perttula 2011:Figure 6-66a). The other distinctive sherd has a cross-hatched engraved zone (see Figure 3f); this sherd may be from Var. G or Var. M. of Poynor Engraved, both varieties with cross-hatched engraved panels (Perttula 2011:Figure 6-65); it is not known when these styles of Poynor Engraved were made by Frankston phase Caddo potters.

Recent analyses of the character of ancestral Caddo ceramic sherd assemblages in the upper Neches River basin in East Texas have indicated several temporal changes in the proportion of brushed sherds in decorated 
sherd assemblages; the percentage of other wet paste decorations (i.e., incised, incised-punctated, punctated, etc.) on sherds; changes in the ratio of plain to decorated sherds (P/DR); and the ratio of brushed sherds to other wet paste decorated sherds (Table 3 ). These analyses have led to the recognition of six temporal sequent groups of assemblages, dating from as early as ca. A.D. 1000-1200 in the Early Caddo period (Group VI) to Historic Caddo ceramic assemblages (Group I) that date after ca. A.D. 1680.

Table 3. Comparative sherd assemblage data from Lake Palestine Caddo sites, nearby Caddo sites, and 41SM91 in the upper Neches River basin.

\begin{tabular}{|c|c|c|c|c|c|c|}
\hline Site & $\begin{array}{l}\text { No. of Dec. } \\
\text { Sherds }\end{array}$ & $\begin{array}{l}\text { \%Brushed } \\
\text { temper }\end{array}$ & $\begin{array}{l}\text { \%bone- } \\
\text { decorations }\end{array}$ & $\begin{array}{l}\% \text { Wet-paste } \\
\text { paste ratio }\end{array}$ & $\mathrm{P} / \mathrm{DR}$ & Brushed/Wet \\
\hline \multicolumn{7}{|c|}{ YOUNGEST SITES: GROUP I, Allen phase, ca. post-A.D. 1680} \\
\hline $41 \mathrm{CE} 421 *$ & 1805 & 88.1 & 5.4 & 7.8 & 0.28 & 8.5 \\
\hline $41 \mathrm{CE} 429 *$ & 465 & 87.7 & 0.8 & 9.7 & 0.22 & 9.07 \\
\hline Pine Snake* & 305 & 85.2 & 5.7 & 8.8 & 0.51 & 9.63 \\
\hline 41CE354* & 474 & 82.7 & 3.1 & 8.9 & 0.20 & 8.14 \\
\hline \multicolumn{7}{|c|}{ GROUP II, latest Frankston phase, ca. A.D. 1560-1680 } \\
\hline 41CE324 & 188 & 81.9 & 3.2 & 7.3 & 0.48 & 11.0 \\
\hline Debro & 311 & 80.0 & $?$ & 10.3 & 0.14 & 7.75 \\
\hline 41SM91 & 191 & 75.9 & 0.7 & 14.7 & 0.51 & 5.18 \\
\hline $\begin{array}{l}\text { William } \\
\text { Sherman }\end{array}$ & 525 & 75.8 & $?$ & 16.2 & 0.44 & 4.68 \\
\hline \multicolumn{7}{|c|}{ GROUP III, Frankston phase, ca. A.D. 1480-1560 } \\
\hline Forest Drive & 1693 & 68.6 & $?$ & 21.9 & 0.56 & 3.12 \\
\hline Halbert & 1757 & 65.8 & 2.6 & 26.3 & 0.70 & 2.51 \\
\hline Woldert & 1730 & 62.7 & 0.0 & 28.8 & 0.72 & 2.19 \\
\hline Ferguson & 4116 & 60.8 & $<1.0$ & 27.9 & 0.61 & 2.17 \\
\hline \multicolumn{7}{|c|}{ GROUP IV, earliest Frankston phase, ca. A.D. 1400-1480 } \\
\hline Tomato Patch & 912 & 49.2 & $?$ & 41.7 & 1.50 & 1.21 \\
\hline Lang Pasture & 2435 & 35.9 & 6.7 & 38.0 & 1.40 & 0.91 \\
\hline Mitchell, D & 54 & 32.1 & 0.0 & 33.3 & 1.37 & 1.50 \\
\hline \multicolumn{7}{|c|}{ GROUP V, Middle Caddo period, ca. A.D. 1200-1400 } \\
\hline M. S. Roberts & 270 & 21.1 & 14.1 & 63.0 & 1.90 & 0.34 \\
\hline 41SM404 & 446 & 16.0 & 8.5 & 60.7 & 1.73 & 0.26 \\
\hline White Mule & 1404 & 18.5 & 1.5 & 63.7 & 2.61 & 0.29 \\
\hline 41HE139 & 40 & 17.5 & 8.1 & 65.0 & 2.51 & 0.33 \\
\hline \multicolumn{7}{|c|}{ OLDEST SITE: GROUP VI, Early Caddo period, ca. A.D. 1000-1200 } \\
\hline Mitchell, A-C & 56 & 1.3 & 12.0 & 65.7 & 1.71 & 0.03 \\
\hline
\end{tabular}

$\mathrm{P} / \mathrm{DR}=$ plain to decorated sherd ratio

*sites with Patton Engraved sherds

?=information not provided in Anderson et al. (1974)

Using these sherd assemblage metrics to assess the temporal placement of the Caddo occupation at 41SM91 indicates that the occupation may well date to the middle part of the Late Caddo period Frankston phase, especially given the proportion of brushed sherds and the proportion of other decorated wet paste 
sherds (see Table 3). Given the overall character of the sherd metrics summarized in Table 3, I suggest that the Caddo occupation of 41SM91 may well have begun in the mid-16th century, and ended sometime in the late Frankston phase (Group II).

\section{Ceramic Pipe Sherd Assemblage}

There are two ceramic elbow pipe sherds in the artifact assemblage from 41SM91. The first is a Var. $B$ elbow pipe fragment. This elbow pipe form has a flaring bowl and a distal stem knob, with three horizontal engraved lines on the stem and lower bowl (Perttula 2011:215 and Figure 6-23). Such pipes have been found in ca. A.D. 1400-1560 contexts at a number of upper Neches River basin sites, generally consistent with the ceramic sherd data discussed above. The other elbow pipe sherd is from a Neches style grog-tempered pipe (see Jackson 1933) with at least one row of small circular punctations on the heel or base of the bowl.

\section{Summary and Conclusions}

41SM91 is a Frankston phase habitation site on an upland landform east of the Neches River in the upper Neches River basin. The site was recorded in 1957 during the course of an archaeological survey of then proposed Blackburn Crossing Reservoir, now Lake Palestine. During the archaeological survey a large assemblage of plain and decorated Caddo vessel sherds was collected, along with two decorated elbow pipe sherds. The stylistic character of the utility ware and fine ware sherds, as well as the elbow pipe sherds, indicates that this Caddo site was likely occupied between ca. A.D. 1560-1650 by an ancestral Caddo group affiliated with a larger community in the upper Neches River basin. The specific ethnic identity of this ancestral Caddo group is not known, as no Caddo groups were living in this part of East Texas at the time European explorers and chroniclers visited the area. Ancient DNA analyses of human remains from ancestral Caddo sites in this region, as well as in other East Texas locales would provide important and unique insights into the native history of the Caddo peoples from the time of the earliest known Caddo settlements in East Texas.

\section{Acknowledgments}

Marybeth Tomka facilitated the study of the ceramic vessel and pipe sherd assemblage from 41SM91 in the collections at the Texas Archeological Research Laboratory at The University of Texas. Sandy Hannum and Lance Trask prepared figures for this article.

\section{References Cited}

Anderson, K. M., K. Gilmore, O. F. McCormick III, and E. P. Morenon

1974 Archaeological Investigations at Lake Palestine, Texas. Contributions in Anthropology No. 11. Department of Anthropology, Southern Methodist University, Dallas.

Jackson, A. T.

1933 Some Pipes of East Texas. Bulletin of the Texas Archeological and Paleontological Society 5:69-86.

Johnson, L., Jr.

1961 An Archeological Survey of Blackburn Crossing Reservoir on the Upper Neches River. Bulletin of the Texas Archeological Society 31:213-238.

Perttula, T. K.

2011 The Ceramic Artifacts from the Lang Pasture Site (41AN38) and the Place of the Site within an Upper Neches River Basin Caddo Ceramic Tradition. In Archeological Investigations at the Lang Pasture Site (41AN38) in the Upper Neches River Basin of East Texas, assembled and edited by T. K. Perttula, D. B. Kelley, and R. A. Ricklis, pp. 145-320. Archeological Studies Program Report No. 129, Texas Department of Transportation, Environmental Affairs Division, Austin. 
Suhm, D. A. and E. B. Jelks (editors)

1962 Handbook of Texas Archeology: Type Descriptions. Special Publication No. 1, Texas Archeological Society, and Bulletin No. 4, Texas Memorial Museum, Austin. Reprinted in 2009, Gustav's Library, Davenport, Iowa. 